\title{
Sexual and reproductive health for young people in Africa: a strong government-led multisectoral approach is urgently needed
}

\author{
Peter Waiswa ${ }^{1,2,3,4}$
}

Received: 8 April 2020 / Revised: 8 April 2020 / Accepted: 27 April 2020/Published online: 12 May 2020

(C) Swiss School of Public Health (SSPH+) 2020

Young people are said to be "the future" of the world. Holding this to be true, then Africa is "the future" of the world-but that only if the potential of its young people is fully harnessed. Unfortunately, currently that does not seem to be the case. Africa is estimated to have a population of 1.2 billion people, of whom $20 \%$ are young people aged between 14-24 years (United Nations 2016). By 2030, the target date for the sustainable development goals (SDG, United Nations 2015), the number of youth in Africa might have increased by $42 \%$. Africa's youth population is expected to continue to grow throughout the remainder of the twenty-first century, more than doubling from current levels by 2055. This huge population of young people can be harnessed and thus spar human capital developmentthrough what is called the "demographic dividend". The United Nations Population Fund (2016) defines the demographic dividend as "the economic growth potential that can result from shifts in a population's age structure, mainly when the share of the working-age population (15-64) is larger than the non-working-age share of the population (14 and younger, and 65 and older)". Unfortunately, unless Africa addresses the sexual and

This Editorial is part of the special issue "Sexual and reproductive health of young people-Focus Africa".

Peter Waiswa

pwaiswa@musph.ac.ug

https://www.mnh.musph.ac.ug

1 Department of Health Policy, Planning and Management, Makerere University School of Public Health,

P.O Box 7072, Kampala, Uganda

2 Global Health Division, Karolinska Institutet, Stockholm, Sweden

3 Leader Makerere University Maternal and Newborn Centre of Excellence, Kampala, Uganda

4 The INDEPTH Network Maternal Newborn and Child Health Research, Kampala, Uganda reproductive health $(\mathrm{SRH})$ of its young people, the demographic dividend cannot be achieved.

One of the major challenges of young people today in Africa emanates from their sexual and reproductive health and rights. Good sexual and reproductive health is defined as a state of complete physical, mental and social wellbeing in all matters relating to the reproductive system. It implies that people are able to have a satisfying and safe sex life, the capability to reproduce, and the freedom to decide if, when, and how often to do so. The International Conference on Population and Development Programme of Action (United Nations Population Fund 2014) and the 2030 SDG Agenda (United Nations 2015) reaffirm the centrality of universal access to sexual and reproductive health and rights to sustainable development, leaving no one behind the SDG target 3.7, which calls for universal access to sexual and reproductive healthcare services including family planning, information, education, and integration of reproductive health into strategies and programs.

Unfortunately, the majority of young people in Africa do not experience good sexual and reproductive health and rights. The sexual and reproductive health challenges facing young people are the product of the inherent characteristics of the young people and the environment in which they live. The youth are typically a highly energic group with characteristic risk-taking behavior. The typical African setting is characterized by poverty, unplanned rapid urbanization, limited access to social services, gender inequalities, political instability among others. As a consequence, there is limited good environment for protecting and nurturing young people. Problems such as illiteracy, high fertility, poor access to sexual and reproductive health education, intimate partner violence, gender inequity, stigma, discrimination, judgmental treatment, lack of confidentiality, drug addiction and inability to physically access services are important barriers to care for adolescents in Africa (United Nations Population Fund 2008). A 
poor state of sexual and reproductive health and rights also kills. Globally, maternal mortality is the second largest cause of deaths among adolescent girls aged 15-19. Of all births globally each year, around 16 million (11\%) are among girls in this age range; about 2 million are among girls under the age of 15 (WHO 2020).

The attainment of the SDG target 3.7 will need a comprehensive multisectoral evidence-based focus on the youth because they contribute a big chunk of the population. On a positive note, many countries in Africa have invested in various infrastructure that provides the SRH services in general. However, these may not necessarily serve the young because they are a unique group that requires a variation in approaches (McManus 2014). To optimize the potential of young people in Africa, more solutions such as school-based programs, outreaches, integration in cross-sector programs are urgently needed. In this interconnected world with globalization, Africa's young people are not only important to Africa, but also to the world. For instance, as Europe ages, Africa has the potential to provide the future workforce and consumption that will spar the world. The potential of young people is a catalyst to social and economic development, which makes investing in young people's education and health a global priority. But this requires continuous investments in young people through nutrition, health care, access to sexual and reproductive health education, quality education, jobs and skills in order to maximize their human developmental potential (World Bank 2019). I call upon national governments and communities to take the drivers seat, and the partners and the United Nations to support.

\section{Compliance with ethical standards}

Conflict of interest The author declares that he has no conflicts of interest.

\section{References}

McManus M (2014) The promise and potential of adolescent engagement in health. J Adolesc Health 55(3):314. https://doi. org/10.1016/j.jadohealth.2014.06.011

United Nations (2015) Transforming our world. The 2030 agenda for sustainable development. https://sustainabledevelopment.un.org/ content/documents/21252030\%20Agenda $\% 20$ for $\% 20$ Sustain able\%20Development\%20web.pdf. Accessed 30 March 2020

United Nations (2016) The demographic profile of African countries. https://www.uneca.org/sites/default/files/PublicationFiles/demo graphic_profile_rev_april_25.pdf. Accessed 30 March 2020

United Nations Population Fund (2008) Maternal and newborn health thematic fund. https://www.unfpa.org/maternal-and-newbornhealth-thematic-fund. Accessed 08 April 2020

United Nations Population Fund (2014) Programme of action of the international conference on population development. https:// www.unfpa.org/events/international-conference-population-anddevelopment-icpd. Accessed 30 March 2020

United Nations Population Fund (2016) Demographic dividend https://www.unfpa.org/demographic-dividend. Accessed 30 March 2020

WHO (2020) Adolescent pregnancy. https://www.who.int/newsroom/fact-sheets/detail/adolescent-pregnancy. Accessed 08 April 2020

World Bank (2019) Ending learning poverty: what will it take? https://openknowledge.worldbank.org/bitstream/handle/10986/ 32553/142659.pdf? sequence $=7 \&$ isAllowed $=y$. Accessed 20 January 2020

Publisher's Note Springer Nature remains neutral with regard to jurisdictional claims in published maps and institutional affiliations. 